\title{
NBSIR 74.594 \\ Examination of Failed Four Inch \\ Cast Iron Pipe Natural Gas Main, \\ Philadelphia Gas Works, \\ Philadelphia, Pennsylvania
}

T. R. Shives

Mechanical Properties Section

Metallurgy Division

Institute for Materials Research

National Bureau of Standards

Washington, D. C. 20234

October 1974

Failure Analysis Report

Prepared for

Office of Pipeline Safety

Department of Transportation

Washington, D. C. 20590 



\section{EXAMINATION OF FAILED FOUR INCH \\ CAST IRON PIPE NATURAL GAS MAIN, PHILADELPHIA GAS WORKS, PHILADELPHIA, PENNSYLVANIA}

\section{T. R. Shives}

Mechanical Properties Section

Metallurgy Division

Institute for Materials Research

National Bureau of Standards

Washington, D. C. 20234

October 1974

Failure Analysis Report

"This document has been prepared for the use of the Office of Pipeline Safety, Department of Transportation, Washington, D.C. Responsibility for its further use rests with that agency. NBS requests that if release to the general public is contemplated, such action be taken only after consultation with the Office of Public Affairs at the National Bureau of Standards."

\section{Prepared for}

Office of Pipeline Safety

Department of Transportation

Washington, D. C. 20590

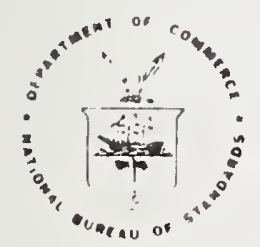

U. S. DEPARTMENT OF COMMERCE, Frederick B. Dent, Secretary NATIONAL BUREAU OF STANDAROS, Richard W. Roberts. Director 

1. INTRODUCTION $\ldots \ldots \ldots \ldots \ldots \ldots \ldots \ldots \ldots \ldots \ldots \ldots \ldots$

1.1 Reference $\ldots \ldots \ldots \ldots \ldots \ldots \ldots \ldots \ldots \ldots \ldots \ldots$

1.2 Background Information ............... I

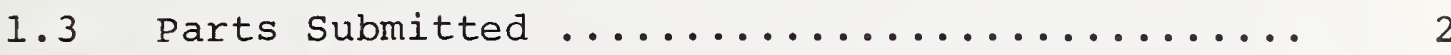

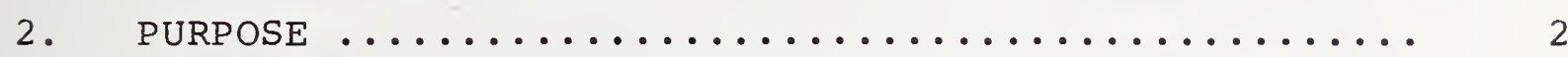

3. PLAN OF THE EXAMINATION $\ldots \ldots \ldots \ldots \ldots \ldots \ldots \ldots \ldots \ldots$

4. RESULtS OF TESTS, EXAMINATIONS, AND ANALYSES ...... 2

4.1 Visual and Macroscopic Examinations ........ 2

4.2 Fractographic Examination with the Scanning Electron Microscope ........... 4

4.3 Chemical Analysis ................... 4

4.4 Metallographic Examination .............. 5

4.5 Hardness Tests ........................ 6

5. DISCUSSION $\ldots \ldots \ldots \ldots \ldots \ldots \ldots \ldots \ldots \ldots \ldots \ldots \ldots \ldots \ldots \ldots \ldots \ldots \ldots$

6. CONCLUSIONS $\ldots \ldots \ldots \ldots \ldots \ldots \ldots \ldots \ldots \ldots \ldots \ldots \ldots \ldots \ldots \ldots$

7. ACKNOWLEDGENENT $\ldots \ldots \ldots \ldots \ldots \ldots \ldots \ldots \ldots \ldots \ldots \ldots$

REFERENCES $\ldots \ldots \ldots \ldots \ldots \ldots \ldots \ldots \ldots \ldots \ldots \ldots \ldots \ldots \ldots \ldots \ldots \ldots \ldots \ldots$

FIGURES

1. Lengths of the gas main pipe and service taps as

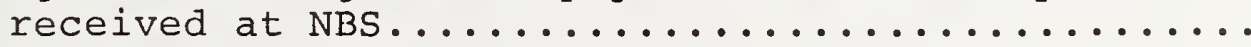

2. Opposing fracture surfaces as received $\ldots . \ldots \ldots \ldots$

3. North fracture surface after ultrasonic cleaning ...

4. Area $A$ of the fracture surface shown in figure $3 \ldots$ 
FIGURES (Continued)

5. Transverse cross section through the pipe two

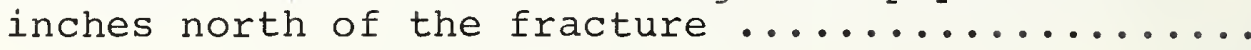

6. Transverse cross section through the pipe nine

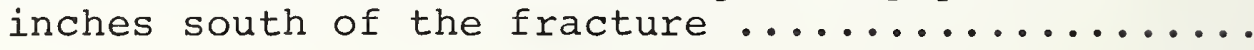

7. SEM fractograph showing the region of apparent

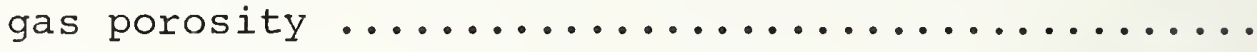

8. SEM fractograph exhibiting features typical of

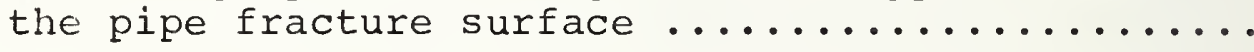

9. SEM fractograph exhibiting features typical of

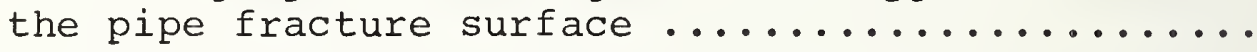

10. Longitudinal section through the top of the pipe

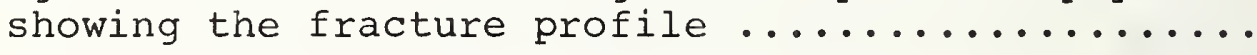

11. Area of figure 10 where the outside wall surface of the pipe intersects the fracture ...........

12. Typical field showing the microstructure of the pipe material

13. Longitudinal section through the top of the pipe ...

14. Three fields from the longitudinal section

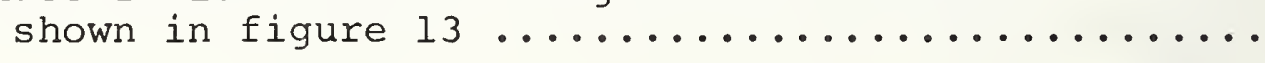




\section{SUMMARY}

The office of Pipeline Safety submitted several pieces of four inch diameter cast iron natural gas main pipe to the National Bureau of Standards Mechanical Properties Section for examination. An accumulation of gas that had escaped from a fracture in the pipeline resulted in an explosion in the 1200 block of South Markoe Street in Philadelphia, Pennsylvania on May 3, 1974. The fracture had occurred in a transverse plane that passed through a service tap hole in the top of the pipe. The fracture was brittle in nature and there was no evidence to indicate the existence of a crack prior to the failure. There was extensive graphitic corrosion in some areas of the pipe, although this does not appear to be related to the failure. A chemical analysis indicated that the phosphorus content of the pipe material was higher than desirable. The microstructure contained a considerable amount of ironiron phosphide eutectic. Failure apparently occurred from a single stressing event caused by bending loads from an external source. 

Examination of Failed Four Inch Cast Iron Pipe Natural Gas Main, Philadelphia Gas Works, Philadelphia, Pennsylvania

\section{INTRODUCTION}

1.1 Reference

Office of Pipeline Safety, Department of Transportation, Washington, D. C. This investigation was conducted at the request of $\mathrm{Mr}$. Lance $\mathrm{F}$. Heverly of the Office of Pipeline Safety under order number DOT-AS-1004l. The request was made on May 21, 1974.

\subsection{Background Information}

The information in this section was furnished by Mr. Lance F. Heverly of the Office of Pipeline Safety, Mr. John F. Flaherty of the Pennsylvania Public Utility Commission, and Messrs. Joseph M. Devereaux and Leonard Orlando of the Philadelphia Gas Works.

On May 3, 1974, there was an explosion at 1213 South Markoe Street in Philadelphia, Pennsylvania, that severely damaged several houses, killed two people, and injured nine others. The explosion was attributed to an accumulation of natural gas that had escaped from a complete fracture in the four inch diameter cast iron gas main pipe located in South Markoe street.

The gas main pipeline was under 36 inches of cover consisting of soil and the roadway pavement. A fourteen foot length of the pipe had been excavated to a depth of several feet below that of the gas main some weeks before the failure in order to service another utility pipeline. The excavation had been only partially refilled at the time of the explosion. The pipe failed about two feet north of the excavation. Just after the part of the pipe containing the fracture had been exposed in the ditch, the top of the pipe at the south fracture face was observed to be approximately at the level of the bottom of the pipe at the north fracture face. The excavation was under water for about 18 hours after the explosion, the water having been used by fire fighting equipment.

The gas main had been installed in about 1897. The service lines in the vicinity of the failure had been installed in the 1920's. Pressure in the main at the time of the accident was $0.25 \mathrm{psig}$. The soil temperature at the point of the fracture was estimated to be about $50^{\circ} \mathrm{F}$. 


\subsection{Parts Submitted}

Three lengths of pipe from the cast iron gas main, one of which contained a service tap, and one separate service tap were submitted for examination. The separate service tap had been located at the point of fracture. The parts were delivered to T. R. Shives of the NBS Mechanical Properties Section by Captain James J. Leonard, Assistant Fire Marshal, City of Philadelphia, and Mr. Harry J. Forr of the Philadelphia Gas Works on May 21, 1974. The parts as received are shown in figure 1 after they had been removed from the shipping crates. The locations from which the pipe pieces had been removed from the ditch are indicated in the figure legend. The total length of gas main pipe submitted was about $43 / 4$ feet.

\section{PURPOSE}

The Office of Pipeline Safety requested the NBS Mechanical Properties section to examine the fractured pipe and, in so far as possible, to determine the cause of failure.

\section{PLAN OF THE EXAMINATION}

At a meeting held at the National Bureau of Standards on June 7, 1974, the general plan of the examination was discussed. This meeting was attended by Mr. Lance F. Heverly of the office of Pipeline Safety, Mr. John F. Flaherty of the Pennsylvania Public Utility Commission, Messrs. Joseph M. Devereaux and Leonard Orlando of the Philadelphia Gas Works, Mr. Kumar Kishinchand of the Philadelphia Water Department, and T. R. Shives of the NBS Mechanical Properties Section. The failure analysis was to include a fractographic examination, a metallographic examination of the pipe material, an examination of the surface condition of the pipe, hardness measurements, and other examinations or tests deemed advisable as the analysis progressed.

\section{RESULTS OF TESTS, EXAMINATIONS, AND ANALYSES}

\subsection{Visual and Macroscopic Examinations}

There was a transverse fracture in the pipe in a plane that passed through the approximate center of the tap hole for the gas service line to the residence at 1213 South Markoe street. The location of the fracture is indicated by the arrow in figure l. The service line, nominally $11 / 4$ inches in diameter, was reported to be of galvanized steel and was attached to the top of the gas main pipe by a threaded joint. The separate service tap shown in figure 1 had been attached to the gas main at the point of the fracture. 
When received at NBS, the fracture surfaces were covered with loosely adhering soil. There was a small amount of loosely adhering soil and a considerable amount of a rather tightly adhering material which appeared for the most part to be soil on the outside wall surfaces of all the submitted pieces of the gas main. There was a considerable amount of soil inside the pipe pieces, especially near the fracture, as can be seen in figure 2 in which the opposing fracture surfaces are shown. It is likely that running water carried the soil into the pipe at the point of fracture, because the failure occurred about two feet north of the partially excavated ditch, and the ditch had water running into it for about 18 hours after the explosion. The soil was removed from the piece of pipe containing the north fracture by ultrasonic cleaning.

There was corrosion product (rust) on both the inside and outside surfaces of the pipe, but the corrosion did not appear by visual examination to be severe enough to significantly affect the integrity of the pipe.

There was also some corrosion product on the fracture surfaces. This corrosion product was removed from the north fracture surface by ultrasonic cleaning. The fracture surface is shown after cleaning in figure 3. Since the product could be easily removed, the corrosion of the fracture surface appeared to be superficial. The corrosion was likely due to exposure to the water after the explosion. The absence of any tightly adhering rust on any portion of the fracture surface indicates that there was no pre-existing crack. There was some evidence of what appeared to be gas porosity (figure 4) on the fracture surface near the bottom of the pipe. The fracture surface had also suffered some mechanical damage, especially adjacent to the inside wall surface. Examples of mechanical damage are indicated by arrows $B$ in figure 3. This damage could have occurred during the removal of the pieces of pipe from the ditch or in subsequent handing.

There was no visual evidence of graphitic corrosion at the fracture surface, but transverse sections through the pipe at distances of 2 and $141 / 2$ inches north of the fracture and 9 and 17 inches south of the fracture did exhibit this type of corrosion. Examples are shown in figures 5 and 6 . In one area near the top of the pipe in the section shown in figure 5, the graphitic corrosion had penetrated nearly the entire wall thickness of the pipe. There was no evidence of. graphitic corrosion in a transverse section $1 / 2$ inch north of the fracture. 
The wall thickness of the pipe varied around the circumference as can be seen in figures 3,5 , and 6 . In the plane of the fracture, the wall thickness ranged from about 0.45 inch at the bottom of the pipe to about 0.33 inch near the top of the pipe. This pipe was installed in the latter part of the 19th century and it is likely that it was produced by the pit casting method.1 It was not uncommon to have such variations in wall thickness of pipe made by this method.

Referring to figure 3 , it is clear that the pipe wall is thinner near the threaded hole than remote from it. The wall thickness is about 0.33 inch at about one-half inch away from the edge of the threaded hole, and about 0.20 inch adjacent to, but not in, the threads. The thinning had occurred on the inside of the pipe.

\subsection{Fractographic Examination with the Scanning Electron Microscope}

Areas of the north fracture surface both near the top and near the bottom of the pipe were examined with the scanning electron microscope. There were no significant differences found in the general fracture appearance among the areas examined except for the area containing the apparent gas porosity (shown in figure 4 by light microscopy). A scanning electron photomicrograph showing the area of gas porosity appears in figure 7. Two scanning electron photomicrographs showing areas typical of the fracture appearance are shown at different magnifications in figures 8 and 9 . The graphite flakes in the cast iron are evident. Very little if any dimpled rupture was detected on the fracture surface indicating that the fracture was of a brittle nature, which would be expected for this material.

\subsection{Chemical Analysis}

A chemical analysis was performed on a sample of the pipe material by a competent commercial laboratory with the following results:

Element

Total carbon

Graphitic carbon

Manganese

Phosphorus

sulfur

Silicon

Nickel

Chromium

Molybdenum

Copper
Per Cent (weight)

$$
\begin{array}{ll} 
& 3.54 \\
& 2.43 \\
& 0.54 \\
& 0.867 \\
& 0.112 \\
& 2.49 \\
< & 0.01 \\
< & 0.01 \\
< & 0.01 \\
< & 0.01
\end{array}
$$


The phosphorus content is higher than is generally desirable. Above about $0.50 \%$, phosphorus can have adverse effects on the mechanical properties of cast iron. 2

\subsection{Metallographic Examination}

An unetched longitudinal section through the top of the pipe showing the fracture profile is shown in figure 10. The fracture profile is at the right, the outside of the pipe wall is at the top, and the inside of the pipe wall is at the bottom. The large, dark areas in the section are regions of porosity. The part of figure 10 showing the intersection of the fracture with the outside surface of the pipe is shown at higher magnification in figure ll. The graphite flakes, which are primarily types $A$ and $C$, are the thin, dark particles. The lack of apparent deformation adjacent to the fracture is characteristic of brittle fracture. There is no apparent graphitic corrosion in this section. An etched field exhibiting the microstructure typical of the cast iron pipe material is shown in figure 12. The microstructure consists primarily of graphite flakes (long, thin, dark gray particles) and pearlite (fingerprint pattern) with small amounts of ferrite (white) and steadite (small rounded phase). This microstructure appears normal for gray cast iron except possibly for the amount of steadite. If present in large enough quantities, steadite, the iron-iron phosphide eutectic, may be detrimental to mechanical properties.2 The amount of steadite present depends on the phosphorus content, and since the phosphorus content was higher than desirable (Section 4.3), it follows that the amount of steadite is probably higher than desirable.

A longitudinal section whose right side is about two inches north of the fracture is shown in figure 13. Extensive graphitic corrosion (dark area) has taken place over the right half of the field shown. At the far right, the graphitic corrosive attack has penetrated nearly the entire wall thickness of the pipe.

Examination revealed that the graphitic corrosion started at the outside surface and proceeded inward. This is illustrated in figure 13. Figures $14 \mathrm{a}, 14 \mathrm{~b}$, and $14 \mathrm{c}$ show, at higher magnification, areas of figure 13 which illustrate essentially no graphitic corrosion, partial graphitic corrosion, and nearly complete graphitic corrosion, respectively. 
Rockwell hardness measurements were made on a transverse section through the pipe two inches north of the fracture. Fifteen measurements made at various points around the circumference ranged from $R_{B} 81$ to $R_{B} 91$ with an average of $R_{B} 88$. This average is approximately equivalent to a Brinell hardness of 176 which is within the range expected for ordinary gray cast iron. 3

\section{DISCUSSION}

This four inch diameter cast iron natural gas main pipe failed transversely through the center of a service tap hole. This hole, which was at the top of the pipe could act as a stress concentrator. The region of the pipe wall surrounding the tap hole was thinner than the pipe wall "away from the tap hole. Both the tap hole and the thinned wall reduced the cross section area of the pipe in the plane of the fracture which, in turn, reduced the load carrying capability of the pipe. Areas of significant graphitic corrosion were found in several transverse planes through the pipe, but there appeared to be no graphitic corrosion at the fracture; hence, whereas the corrosion might be considered to be detrimental, it does not appear to have contributed to the failure of the pipe.

The general corrosion of the inside and outside wall surfaces of the pipe did not appear to be severe enough to have any significant effect on the integrity of the pipe.

The fracture appeared to be brittle in nature, which would normally be expected in cast iron. This is borne out by the fracture features and the lack of apparent deformation adjacent to the fracture. The gas porosity found at the fracture surface and in metallographic cross sections, while not desirable, is not considered to be excessive.

A chemical analysis of the pipe material indicates that there is a higher than desirable phosphorus content. This is borne out by the significant amount of iron-iron phosphide eutectic (steadite) that was present in the microstructure of the pipe material. Steadite is a brittle phase and can have detrimental effects on the mechanical properties of cast iron if present in large enough amounts. Except for the steadite and the regions that had suffered graphitic corrosive attack, the microstructure appeared to be satisfactory.

The hardness of the pipe material as measured on a transverse section was normal for ordinary cast iron. 
The soil in the pipe apparently accumulated subsequent to the failure and had no influence on the cause of the failure.

Since the corrosion product on the fracture surfaces appeared to be superficial, it is concluded that there was no crack prior to the time of the failure of the pipe. Failure was probably the result of a single stressing event caused by loading from an external source such as soil subsidence. The stressing condition may have been aggravated by inadequate support beneath the pipe at the site of the 14 foot long excavation. Evidence of inadequate support and/or a bending stress is the fact that, while the failed pipe was still in place in the ditch, the south fracture face was about a pipe diameter below the north fracture face.

The pipe probably failed where it did due to a combination of circumstances such as 1) the hole at the top of the pipe for the service tap acting as a stress concentrator, 2) reduced cross section in the plane of the fracture because of the tap hole and because of the reduced pipe wall thickness adjacent to the tap hole, and 3) possible constraint applied to the pipe north of the fracture by three sources. These sources are (a) the service line to 1213 South Markoe Street which was attached to the gas main at the point of fracture, (b) the service line to 1211 South Markoe Street which was attached to the gas main about six inches north of the fracture, and (c) the soil north of the fracture that had not been disturbed by the excavation. Failure was apparently caused by a single event bending stress from an external source.

\section{CONCLUSIONS}

1. This four inch cast iron natural gas main pipeline failed in a brittle manner in a transverse plane that passed through the center of a service tap hole.

2. There was no evidence to indicate the existence of a crack prior to the failure.

3. Failure was apparently caused by a single event bending stress due to external loading.

4. The location of the failure is probably related to the tap hole acting as a stress concentrator, the reduced cross section area of the pipe at the plane of the fracture, and possible constraints imposed on the pipeline by the service lines and by the undisturbed soil north of the fracture. 
5. There may have been inadequate support under the pipe over the length of the excavation.

6. The pipe had suffered severe graphitic corrosive attack in some areas, although there was no visual evidence of this corrosion at the fracture.

7. The chemical composition of the pipe material appeared to be satisfactory except for a somewhat higher than desirable phosphorus content.

8. Except for what may be a greater than desirable amount of iron-iron phosphide eutectic content and graphitic corrosion, the microstructure appeared to be satisfactory.

9. The hardness of the pipe appeared to be satisfactory.

\section{ACKNOWLEDGEMENT}

Mr. Leonard C. Smith of the NBS Mechanical Properties Section performed the photographic work, prepared the metallographic specimens, and assisted in other aspects of this investigation.

\section{REFERENCES}

1. Development of the Metal Castings Industry, Bruce L. Simpson, American Foundrymen's Association, 1948.

2. Metal Castings, Harry L. Campbell, John Wiley and Sons, Inc., New York, 1936.

3. Gray and Ductile Iron Castings Handbook, Charles F. Walton, Editor, Gray and Ductile Iron Founders' Society, 1971. 


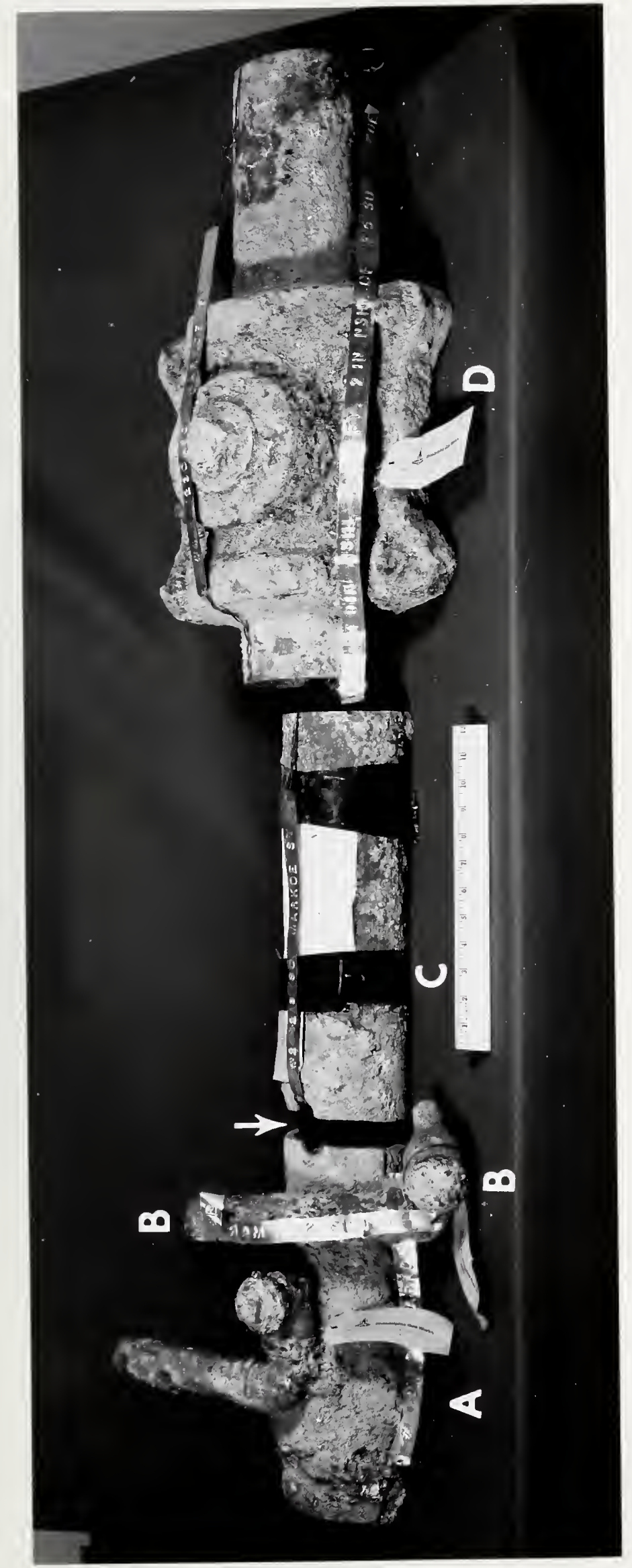

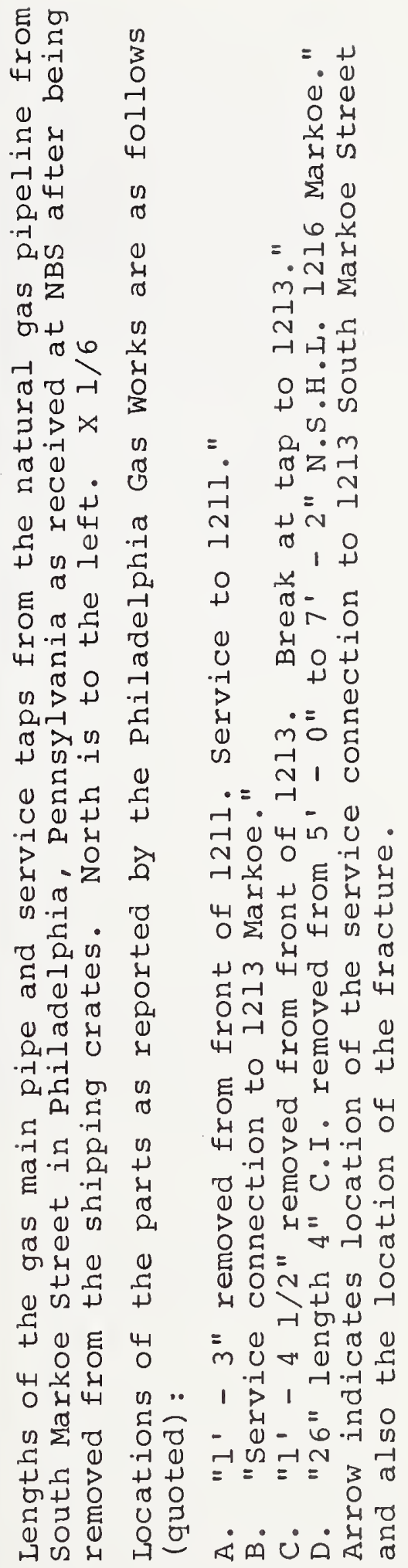





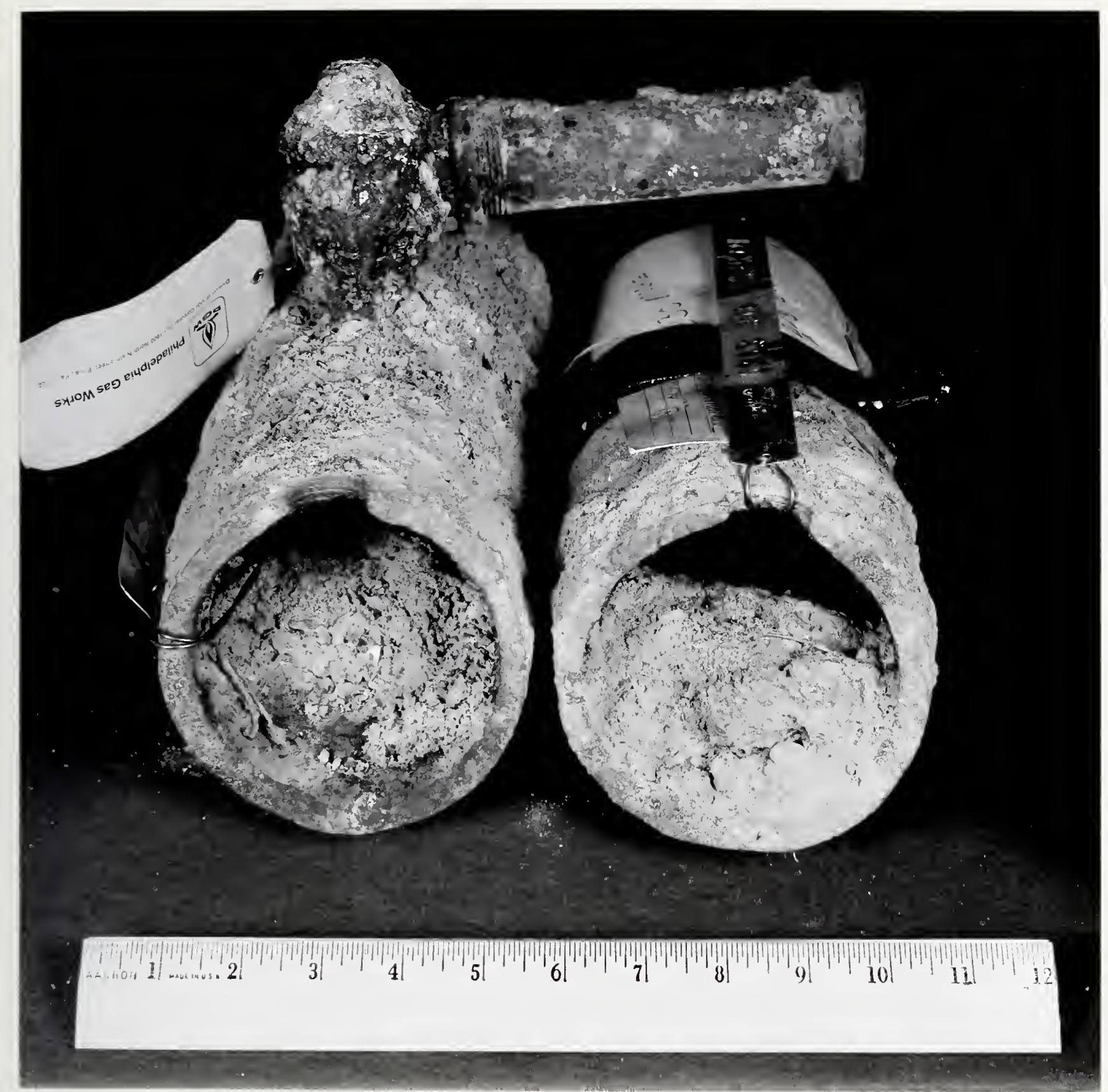

Figure 2. Opposing fracture surfaces as received. The north fracture surface is at the left and the south fracture surface is at the right. Large deposits of soil can be seen inside the pieces of pipe, along with some soil on the fracture surfaces and what appears to be soil adhering to the outside of the pipe. The top of the pipe as installed in the soil is at the top in the photograph. $\times 1 / 2$ 



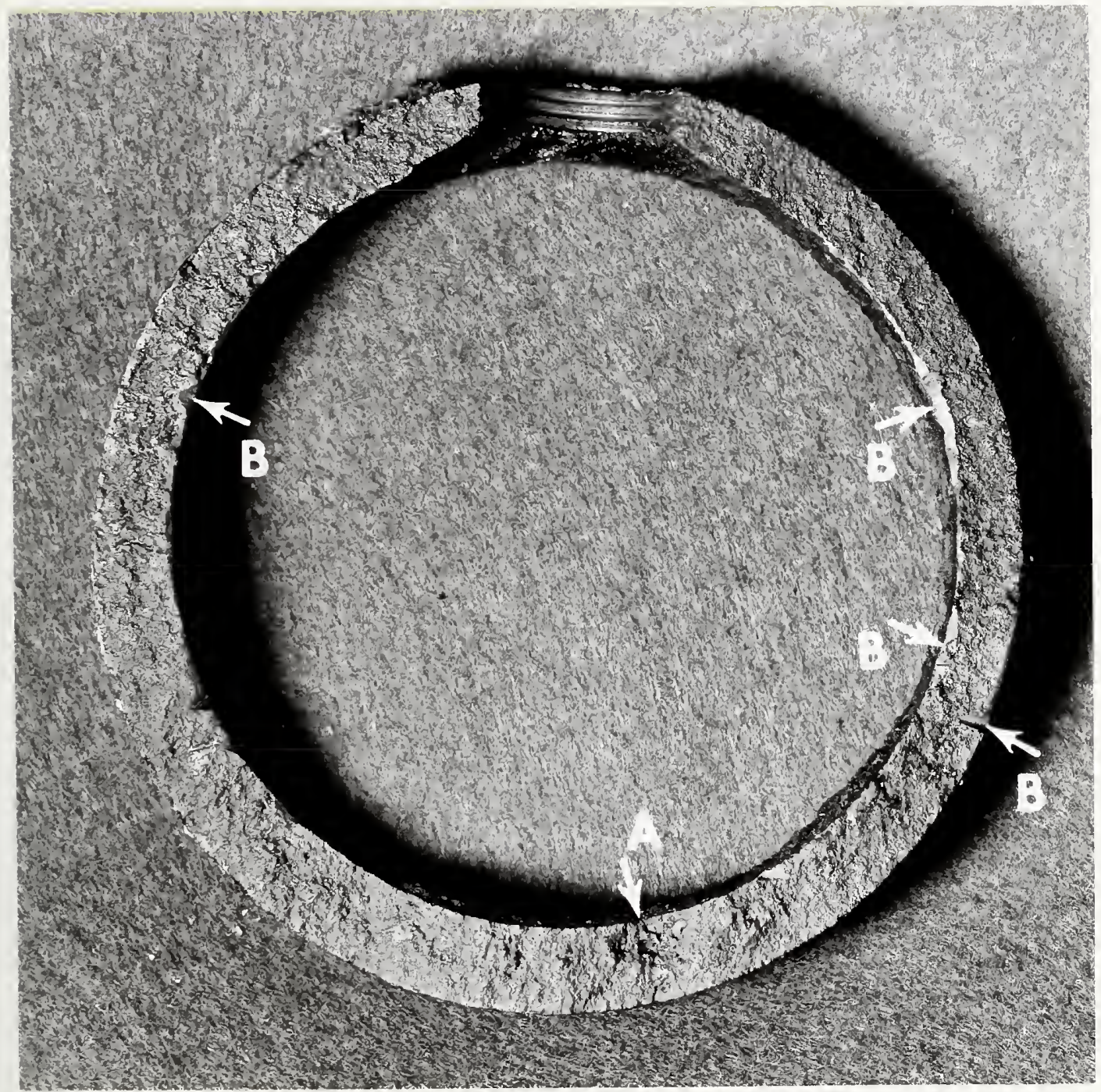

Figure 3. North fracture surface after ultrasonic cleaning. The top of the pipe as installed in the ditch is at the top of the photograph. The threaded region is in the tap hole for the service line to 1213 South Markoe street. Arrow $A$ indicates an area of the fracture surface shown in figure 4. Arrows B indicate examples of mechanical damage. $\mathrm{X} 1$ 



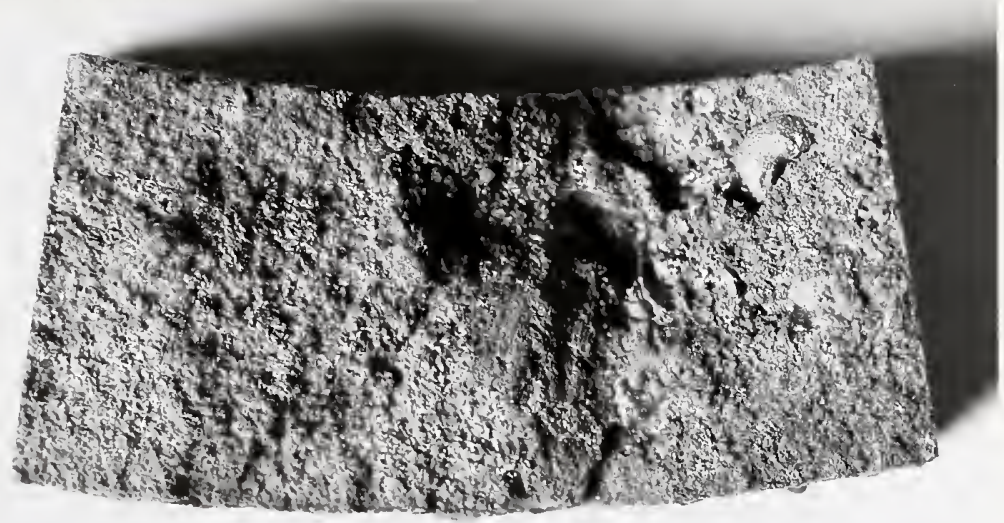

Figure 4. Area A of the fracture surface shown in figure 3. This is a region of apparent gas porosity. $\mathrm{X} 4$

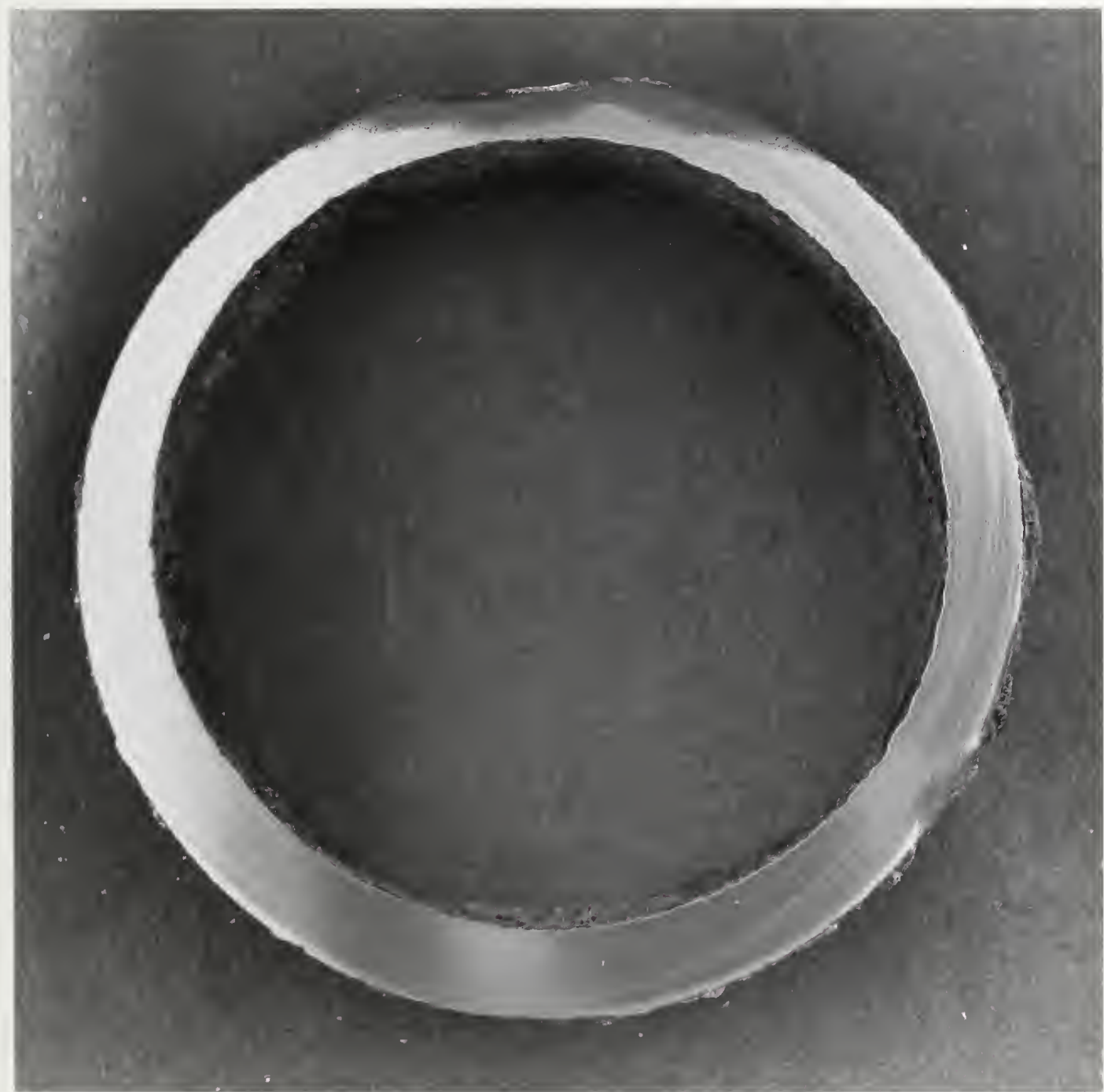

Figure 5. Transverse cross section through the pipe two inches north of the fracture. The dark areas at the top and at about $40^{\prime c l o c k}$ are regions of graphitic corrosion. Top of pipe as installed in the soil is at top of photograph. $\times 1$ 



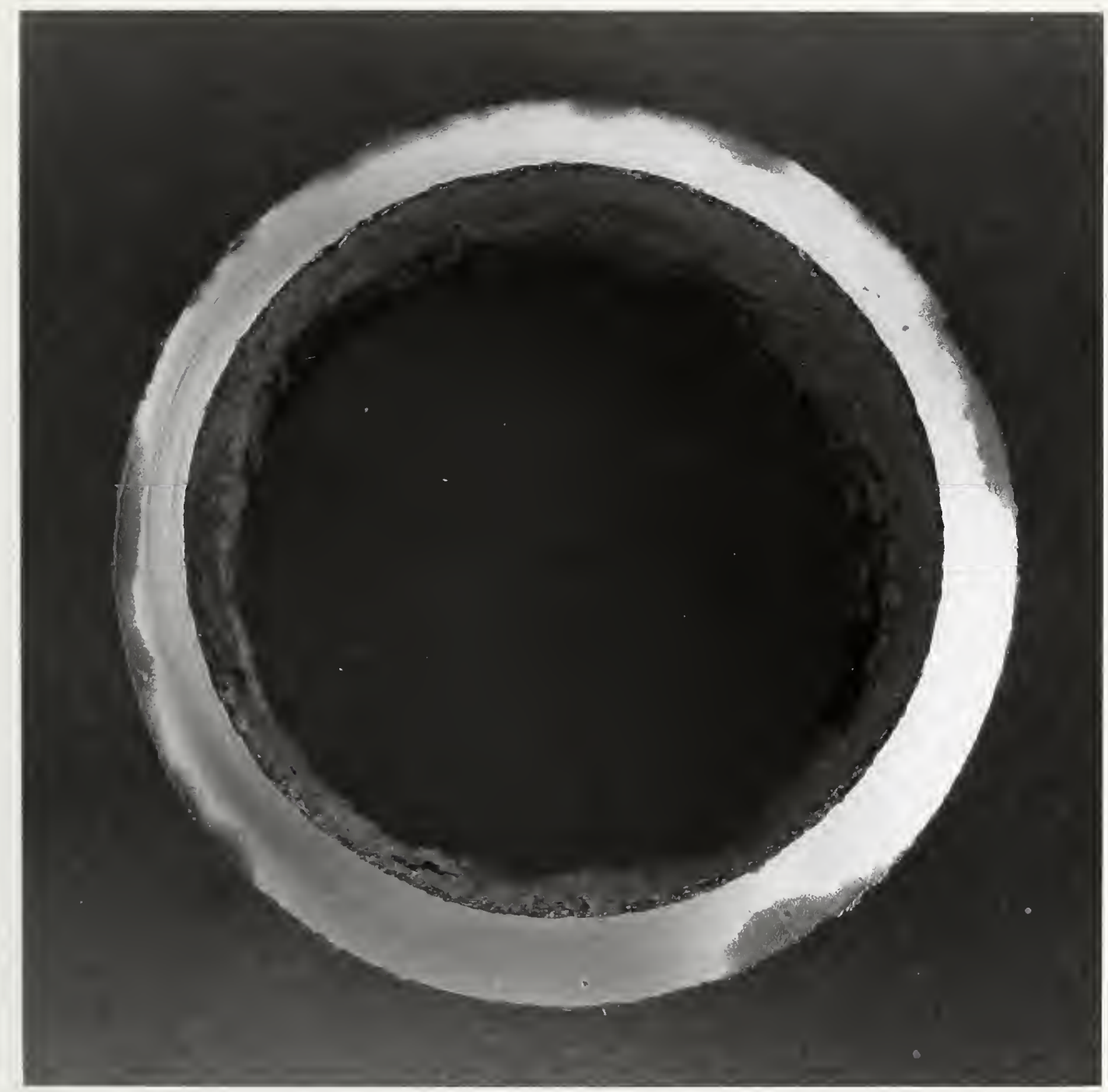

Figure 6. Transverse cross section through the pipe nine inches south of the fracture. Regions that have suffered graphitic corrosion can be seen around much of the circumference. The top of the pipe as installed in the soil is at the top of the photograph. $\mathrm{X} 1$ 



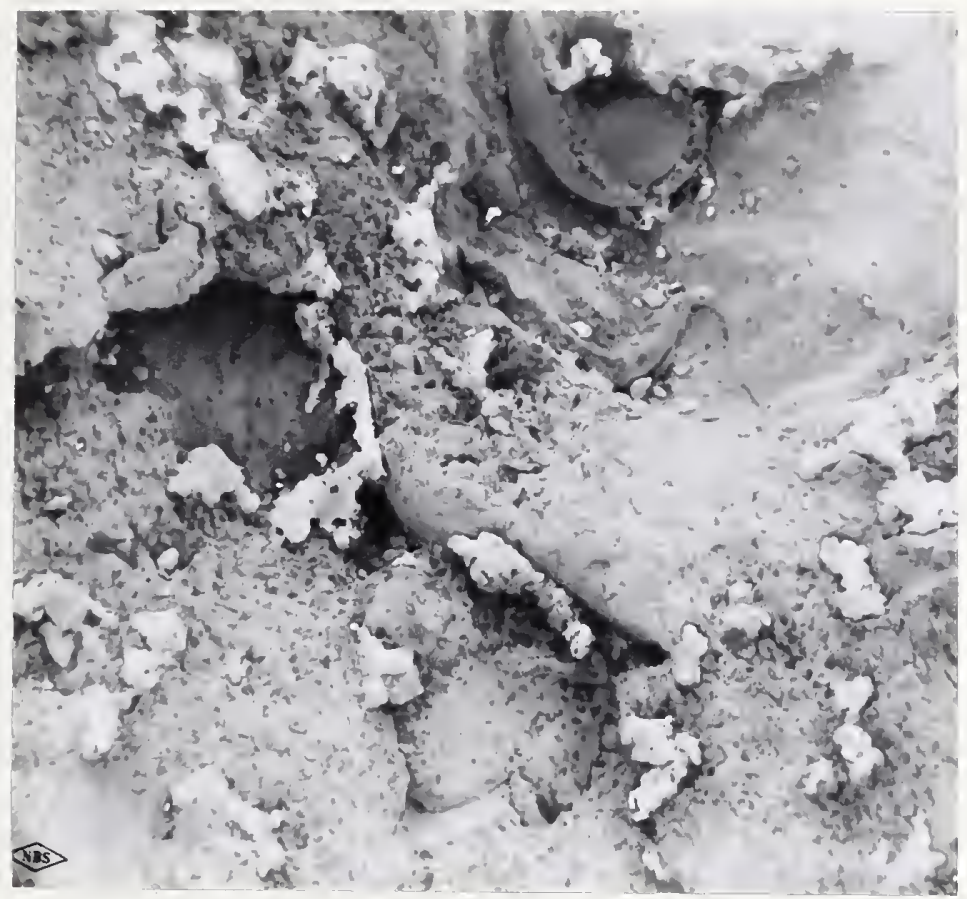

Figure 7. SEM fractograph showing the region of apparent gas porosity (arrow A, figure 3). The patches of very light colored matter are foreign material. X 20

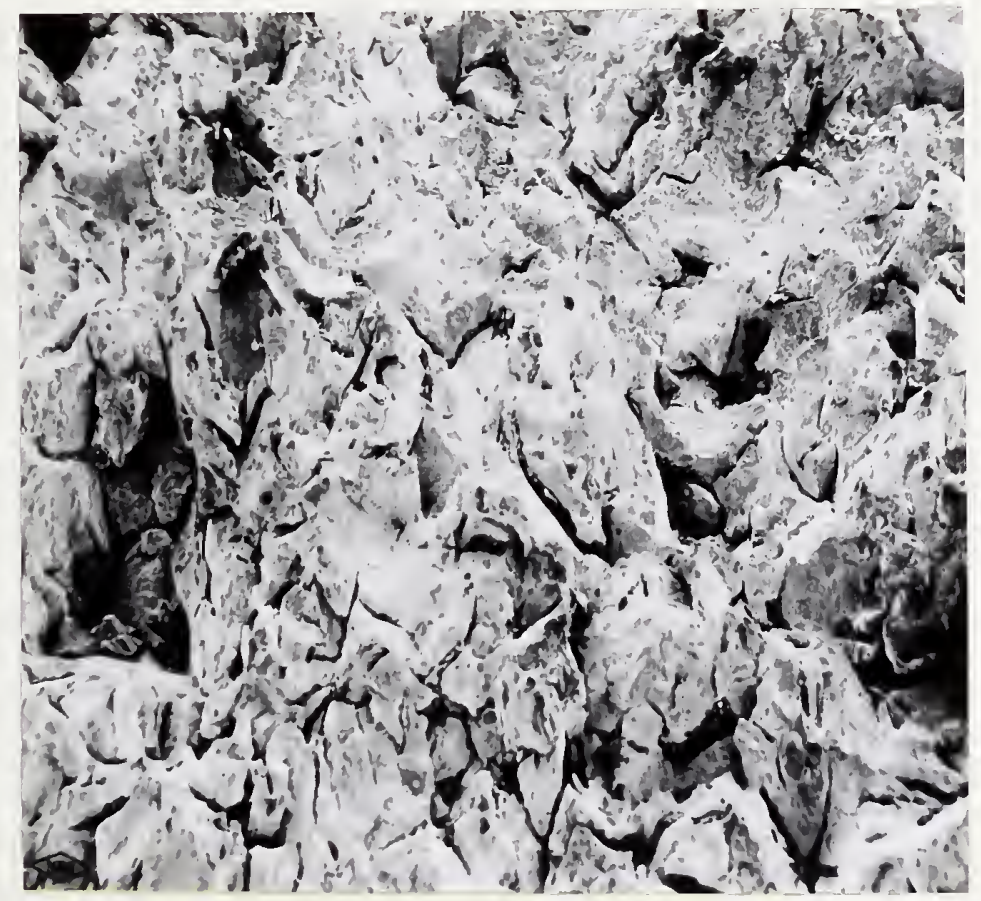

Figure 8. SEM fractograph exhibiting features typical of the pipe fracture surface. In most cases, the narrow dark phase is graphite. $\times 89$ 



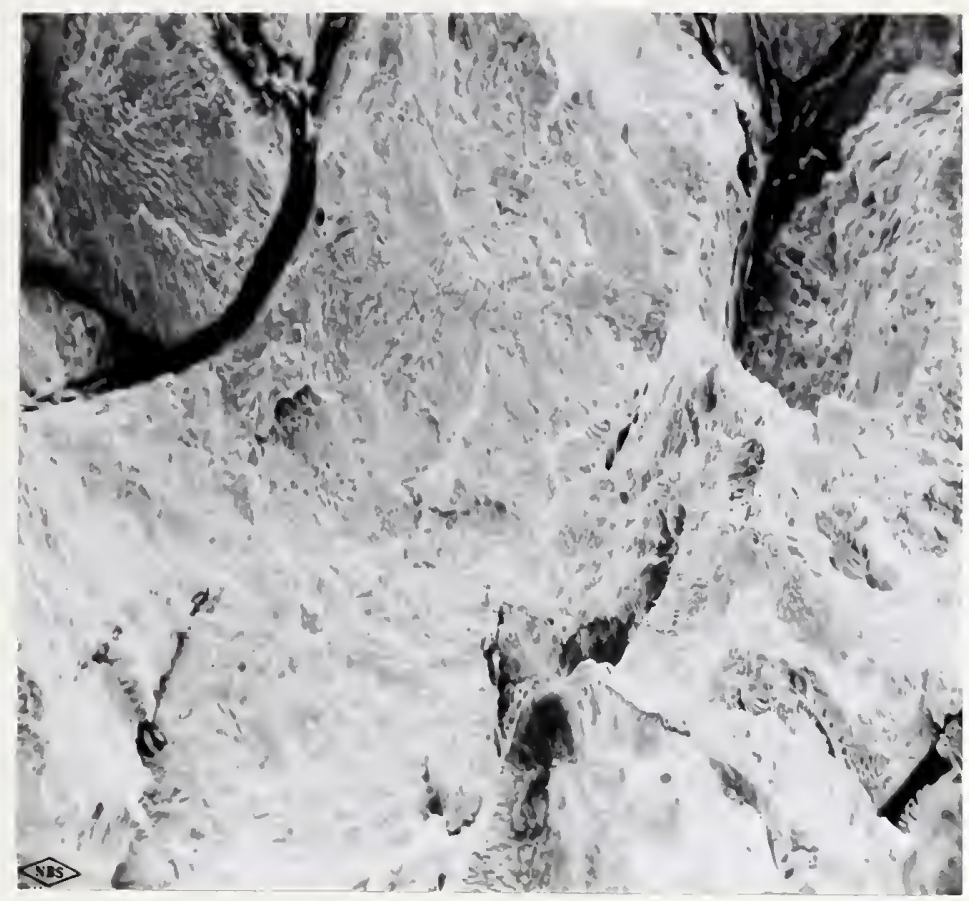

Figure 9. SEM fractograph exhibiting features typical of the pipe fracture surface. This figure is at a higher magnification than that of figure 8. The dark phase is graphite. $\mathrm{X} 460$

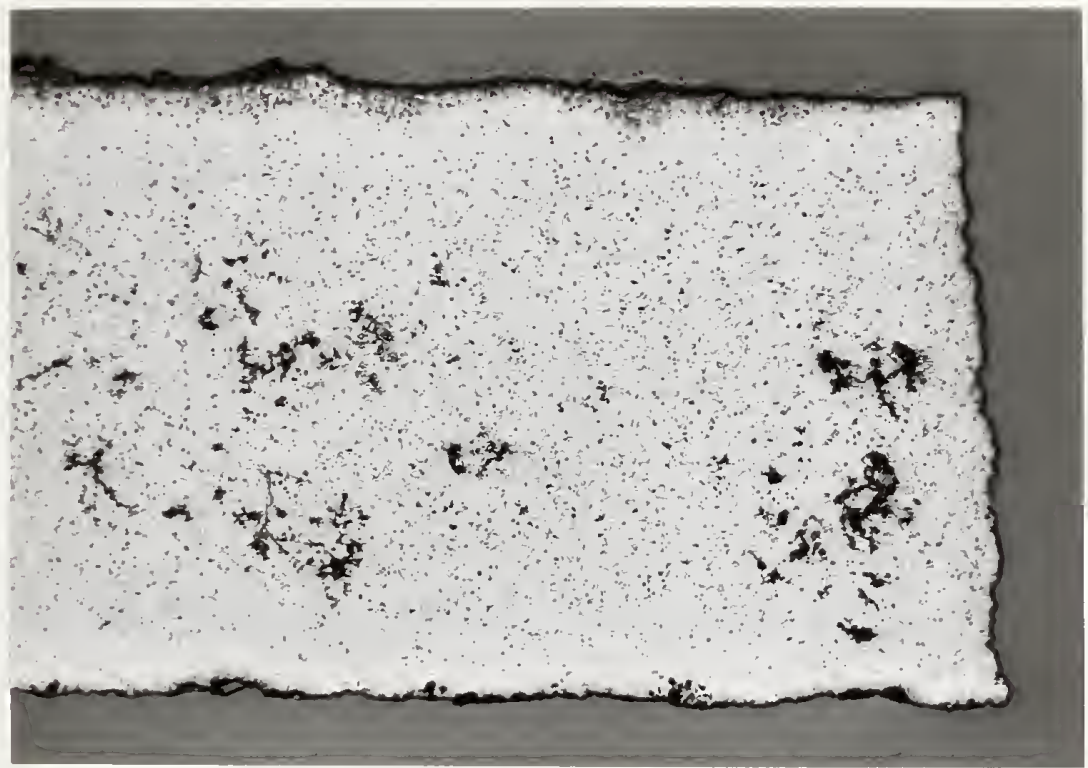

Figure 10. Longitudinal section through the top of the pipe showing the fracture profile at the right. The outside wall surface of the pipe is at the top and the inside wall surface of the pipe is at the bottom. The dark patches are regions of apparent gas porosity. Unetched. X 7.5 



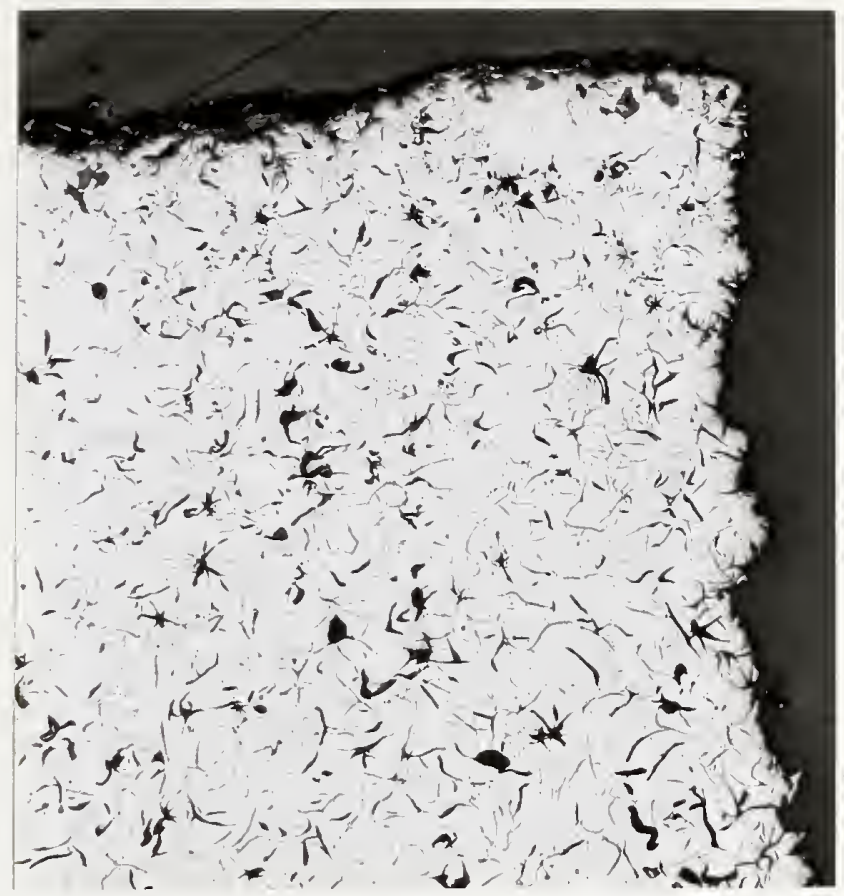

Figure 11. Area of figure 10 where the outside wall surface of the pipe intersects the fracture (vertically at the right). Some general surface corrosion can be seen on the outside wall surface. Most of the dark areas are graphite flakes. Unetched. X 50

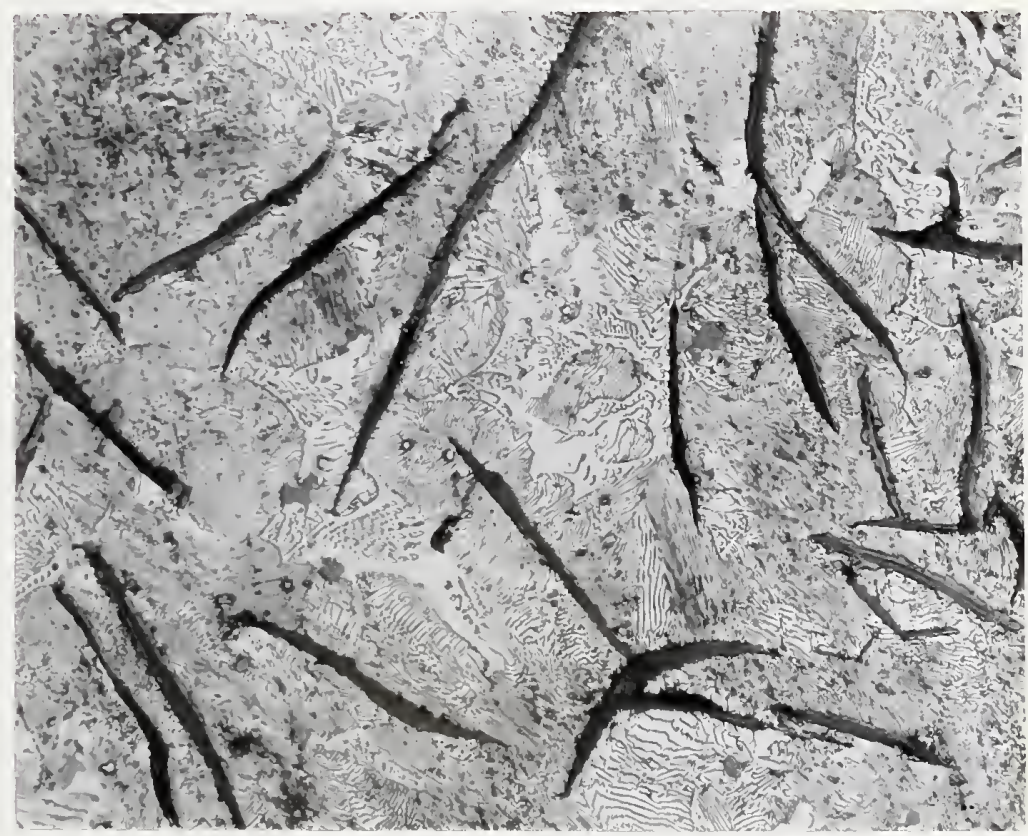

Figure 12. Typical field showing the microstructure of the pipe material. The microstructure consists of graphite flakes (long, thin, dark particles), pearlite (fingerprint pattern), ferrite (white), and steadite (small rounded particles).

Etchant: 18 nital. X 500 



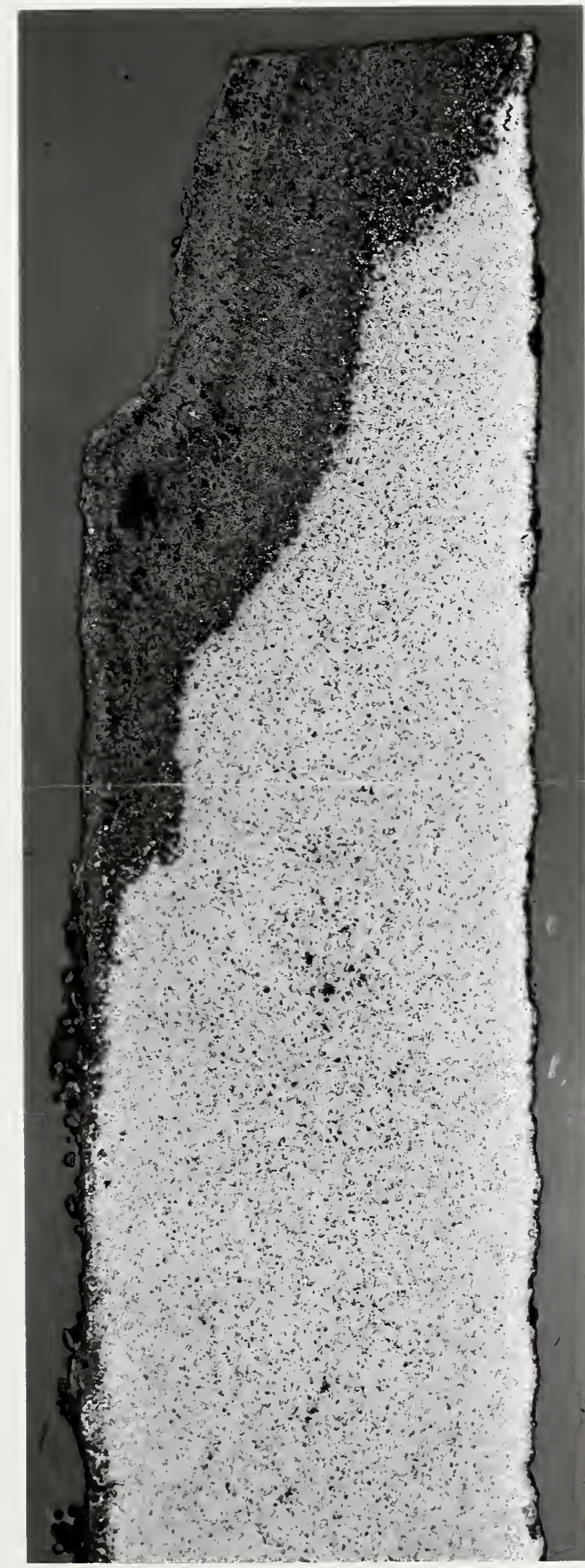

4

(1)

ब)

- 7 त्र.

का

†

त्व

क्षه

E- 突

i. 4

$00+$

-

로 द्ञ

(1) $0 \Omega$

类 4

$\begin{array}{lll}4 & 0 \\ 4 & 0 & 0\end{array}$

出 专

म

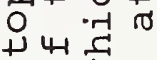
(1) 30 प्र द 0 . 0 - 0 कु 的 गु थ ्ㅏ (4) प्र 4 द्व ON +00 的 $x$ द. न U U म्न 0 .

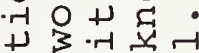
0 岌空 (1) मू. म (n) थ $\pi \cdot 5 \cdot$ ना प्रू ग का द 口 नन 马ु + 0 U 02

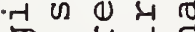

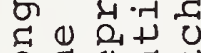
요요요 月十 भ

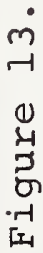




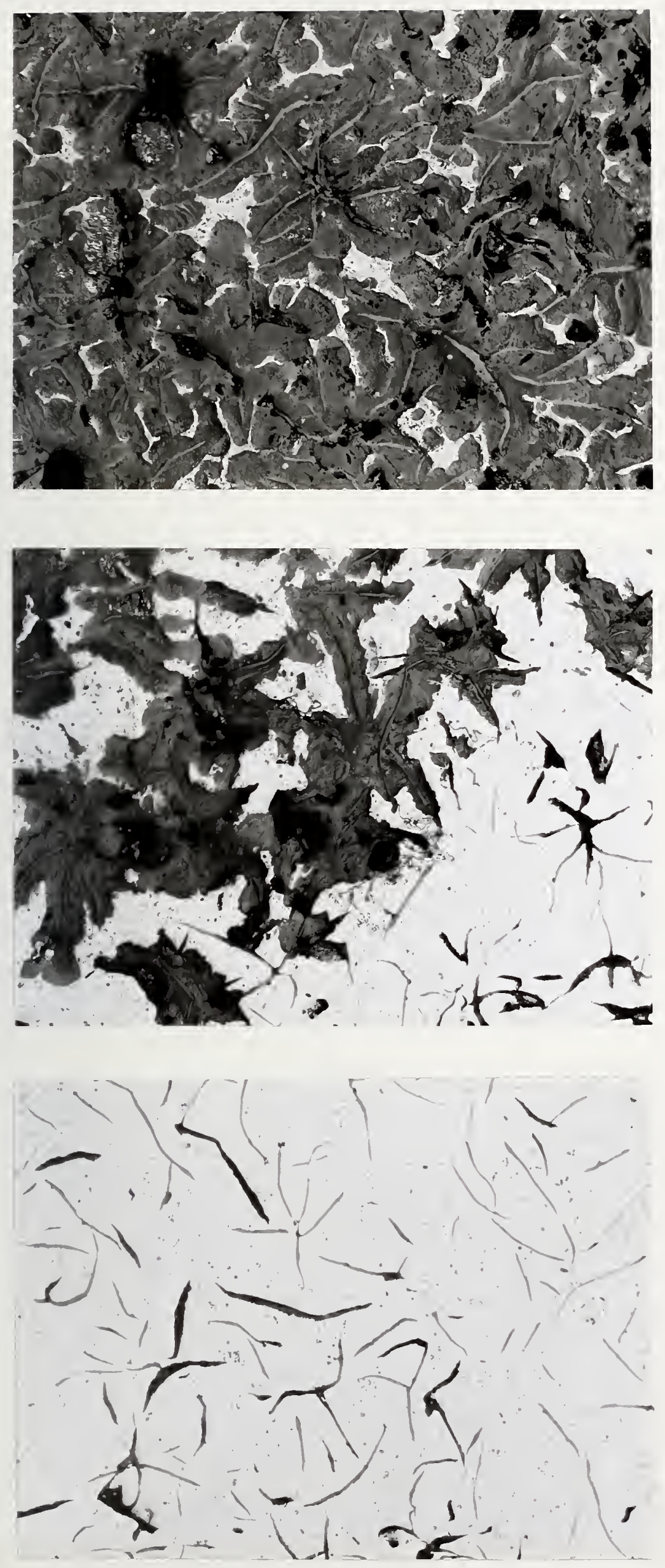



\begin{tabular}{|c|c|c|}
\hline $\begin{array}{l}\text { U.S. DEPT. OF COMM. } \\
\text { BIBLIOGRAPHIC DATA } \\
\text { SHEET }\end{array}$ & $\begin{array}{l}\text { 1. PUIBIIK ATION (OR REPORT NO. } \\
\text { NBSIR } 74-594\end{array}$ & 3. Recipient's Accession No. \\
\hline \multicolumn{2}{|c|}{$\begin{array}{l}\text { 4. TITLF: ANI) SU13 ITI: } \\
\text { EXAMINATION OF FAILED FOUR INCH CAST IRON PIPE } \\
\text { NATURAL GAS MAIN, PHILADELPHIA GAS WORKS, } \\
\text { PHILADELPHIA, PENNSYLANIA }\end{array}$} & $\begin{array}{l}\text { 5. Publication Date } \\
\text { October, } 1974 \\
\text { 6. Performing Organization Code }\end{array}$ \\
\hline \multirow{2}{*}{\multicolumn{2}{|c|}{$\begin{array}{l}\text { 7. AUTIIOR(S) } \\
\text { T. R. ShIVES } \\
\text { 9. PERFORMING ORGANIZATION NAME ANI) ADIIRESS } \\
\text { NATIONAL BUREAU OF STANDARDS } \\
\text { DEPARTMENT OF COMMERCE } \\
\text { WASHINGTON, D.C. 20234 }\end{array}$}} & $\begin{array}{l}\text { 8. Performing } 0 \text { rgan. Report No. } \\
\text { NBSIR } 74-594\end{array}$ \\
\hline & & $\begin{array}{l}\text { 10. Propect/Task/Work Unit No. } \\
3120418 \\
11 . \text { Contract/Grant No. }\end{array}$ \\
\hline \multicolumn{2}{|c|}{$\begin{array}{l}\text { 12. Sponsoring Organization Name and Complete Address (Street, City, State, ZIP) } \\
\text { Office of Pipeline Safety } \\
\text { Department of Transportation } \\
\text { Washington, D. C. } 20590\end{array}$} & $\begin{array}{l}\text { 13. Type of Report \& Period } \\
\text { Covered Failure } \\
\text { Analysis Report } \\
\text { 14. Sponsoring Agency Code }\end{array}$ \\
\hline \multicolumn{3}{|c|}{ 15. SUPPI.IEMENTARY NOTES } \\
\hline \multicolumn{3}{|c|}{$\begin{array}{l}\text { 16. ARSTRAC. (A } 200 \text {-word or less factual summary of most sienificant information. If document includes a significant } \\
\text { bibliography or lterature survey, mention it here.) } \\
\text { The Office of pipeline Safety submitted several pieces of four inch } \\
\text { diameter cast iron natural gas main pipe to the National Bureau of } \\
\text { Standards Mechanical Properties Section for examination. An accumulation } \\
\text { of gas that had escaped from a fracture in the pipeline resulted in an } \\
\text { explosion in the } 1200 \text { block of South Markoe Street in philadelphia, } \\
\text { Pennsylvania on May } 3,1974 \text {. The fracture had occurred in a transverse } \\
\text { plane that passed through a service tap hole in the top of the pipe. } \\
\text { The fracture was brittle in nature and there was no evidence to indicate } \\
\text { the existence of a crack prior to the failure. There was extensive } \\
\text { graphitic corrosion in some areas of the pipe, although this does not } \\
\text { appear to be related to the failure. A chemical analysis indicated that } \\
\text { the phosphorus content of the pipe material was higher than desirable. } \\
\text { The microstructure contained a considerable amount of iron-iron } \\
\text { phosphide eutectic. Failure apparently occurred from a single stressing } \\
\text { event caused by bending loads from an external source. }\end{array}$} \\
\hline
\end{tabular}

17. KEY WORDS (six to twelve entries; alphabetical order; capitalize only the first letter of the first key word unless a proper name; separated by semicolons)

Brittle fracture; cast iron gas pipe; graphitic corrosion; steadite.

18. AVAILABILITY

[X For Official Distribution. Do Not Release to NTIS

Order From Sup. of Doc., U.S. Government Printing Office Washington, D.C. 20402 , SD Cat. No.C13

7 Order From National Technical Information Service (NTIS) Springficld, Virginia 22151

\begin{tabular}{|c|c|}
\hline $\begin{array}{l}\text { 19. SECURITY CLASS } \\
\text { (THIS REPORT) } \\
\text { (UNCLASSIFIED) }\end{array}$ & $\begin{array}{l}\text { 21. NO. OF PAGES } \\
23\end{array}$ \\
\hline $\begin{array}{l}\text { 20. SF( URITY CLASS } \\
\text { (THIS PAGE) } \\
\text { UNCI_ASSIFIED) }\end{array}$ & 22. Price \\
\hline
\end{tabular}






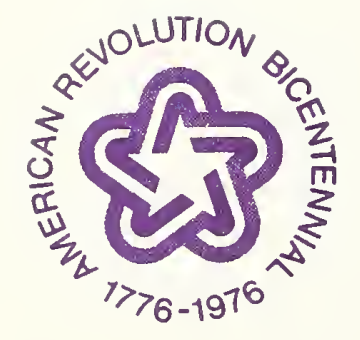

